\title{
GETTING STUDENTS ACTIVELY INVOLVED USING THE 'MISTAKE BUSTER TECHNIQUE” TO IMPROVE THEIR NARRATIVE ESSAY
}

\author{
Diana Luspa \\ diana_luspa@yahoo.com \\ PGRI University of Palembang
}

\begin{abstract}
Checking higher Intermediate 2 level students' narrative essay, an idea to get the students actively involved in improving their narrative essay came up. It could not be by just giving the score and gave it back to them. The mistakes can fossilize. So, the "Mistake Buster Technique" was applied. First, the students applied the "Mistake Buster Technique" by doing peer correction to their narrative essay in their first writing. Second, they used the Mistake Buster Technique" to find and correct the "unidentified mistakes" from their peer correction activity. Their first writing was used as the pretest, while the posttest was taken from their first periodic test. Based on the data analysis, the results of the pretest mean score is 15.48 , and the posttest is 17.14 . The mean difference is 0.004 . The result showed that the 'Mistake Buster Technique" significantly improves students' narrative essay. It also minimized students' grammatical errors. It was indicated by their grammar pretest mean score 3.36 that improved to 5.00 in their grammar posttest mean score. In additional, this technique allows the students to communicate with their peer in identifying and correcting the mistakes. Another benefit is they can collaboratively identify the possible mistakes themselves. It is a creative activity for the students to take over the role of correcting mistakes. Switching the role of the "mistake corrector" can be used to reinforce their critical thinking and problem solving. In short, the" Mistake Buster Technique" is very effective and useful to correct their mistakes.
\end{abstract}

Keywords: Mistake buster technique, improve

\section{Introduction}

Previewing student book on the first day of class should be a routine activity before stating a class. In the sample class, higher intermediate level students of Lembaga Bahasa LIA Palembang, knew that their student book has four skills, reading, writing, listening, and speaking. On the next meeting, they studied a lesson in which writing was the skill focus. In that lesson, the students were required to write a narrative essay based on the outline.

Recalling the previous class that has been taught, students usually have some problems in writing narrative essay. 


\section{ESTEEM JOURNAL OF ENGLISH STUDY PROGRAME \\ P-ISSN 2622-9323 \\ E-ISSN 2622-2213}

The format of a narrative essay was exposed to the students. Then, Jaya et al (2018) the students wrote a narrative essay as their assessment. They did the assignment as a take home task since they didn't have much time to finish the writing.

Jaya et al (2016) Their writing was previewed, some grammatical errors were noticed. Most of them were the past tense forms. Nozadze (2012) said that errors become fossilized when they have become permanently established. It is the mistakes that students know it is wrong but they keep making them, something that students learnt wrong, errors that students

\section{Research methods}

The design in this research is a Classroom Action Research (CAR). The researcher conducted a classroom action research to know and learn the case which occurred in teaching learning process and purposely tried to solve the problem happened. An action research collects and analyzes data to address educational issues. Hopkins (2008:8) stated that:

"To some, the phrase 'classroom research' brings to mind images of whitecoated (or grey-suited!) educational researchers undertaking research in a sample of schools or classrooms and using as subjects the teachers and students who

live out their educational live with them. However, Classroom Action research, is another kind of research primarily for the purpose of improving their teaching and the quality of education in their schools. It might be useful therefore to begin with some examples of teachers who have engaged in systematic enquiry with the purpose of understanding and improving their practice."

Another expert accepts definition of classroom action research. Burns, (2009: 290) stated that:

"Action research is the combination and interaction of two modes of activity action and research. The action is located within the ongoing social processes of 


\section{ESTEEM JOURNAL OF ENGLISH STUDY PROGRAME \\ P-ISSN 2622-9323 \\ E-ISSN 2622-2213}

particular societal contexts, whether they be classrooms, schools, or whole organizations, and typically involves developments and interventions into those processes to bring about improvement and change. The research is located within the systematic observation and analysis of the developments and changes that eventuate in order to identify the underlying rationale for the action and to make further changes as required based on findings and outcomes."

It means that one of the main aims of action research is to identify problematic situation or issue that the participants who may include teachers, students, managers, administrators, or even

\section{Research Results and Discussion}

The data collection methods used in this research was pretest, the posttest, and questionnaire. The first periodic test was conducted. The results of the first periodic test were used as the pretest data. Students had peer correction by using the "Mistake buster technique" and revised their narrative essay. Unidentified mistakes were displayed on the slide show for students to apply the technique to find and correct the mistakes by themselves. The results of second periodic test were used as the posttest data. Then, questionairres were distributed.

Based on the data analysis, the lowest score of the pretest is 12 and the parents consider worth looking into more deeply and systematically."

In short, Classroom Action Research is called a unique research. In plan definition, classroom action research is an action research done by the teacher who seeks for solution in teaching learning process in order to improve the students' achievement. It becomes the foundation for the researcher in considering how important the research design for doing a research is.

highest score of the posttest is 18 . Whereas, the lowest score of the posttest is 13 and the highest score of the posttest is 19. Out of 21 students, 23.8 percent got 14 , and 23.8 percent got 16 in the pretest. In the posttest, 33 percent of the students got 18 , and 19 percent of the students got 16 and 19. It shows that there are some improvements indicated by the results of the posttest. In additional, the result of the pretest mean score is 15.48 , and the result of the posttest is 17.14. The mean difference is 0.004 . The result shows that the "Mistake Buster Technique" significantly improves students' narrative essay. This technique also minimizes 


\section{ESTEEM JOURNAL OF ENGLISH STUDY PROGRAME \\ P-ISSN 2622-9323 \\ E-ISSN 2622-2213}

students' grammatical errors. It is indicated by their grammar pretest mean score 3.36 improves to 5.00 in their grammar posttest mean score.

\section{Interpretations}

Based on the results of the data analyses, the followings are some interpretations to strengthen the value of the study. "Mistake buster technique" improves students' narrative essay. 2)

\section{Conclusion}

The "Mistake Buster Technique" had made the students aware of their writing ability. It gave them the influence to perform better writing performance. The most important is they were actively engaged in identifying the errors and could revise them. It also made them motivated in writing. In conclusion, the "Mis take Buster Technique" is very useful to correct their mistakes.

\section{Suggestion}

Similar activities can be easily be developed by teachers to suit their needs and the students' as well. It is hoped that this technique will be tried out by many teachers and found to be beneficial for both teachers and students.

what are their opinions about the "Mistake Buster Technique". Based the questionnaire distributed to the students, it was the first time for them to apply the correction technique on their mistake. Most of the students did not feel threatened with this kind of activity because in their opinion it is very beneficial and effective for them. It makes them be able to identify the errors.

At the moment, most of the teachers of English are trying their best to make their students improve their written English. Teachers, as error-analyst, look for patterns in the errors of an individual student, try to discover how the mistake arrived at the mistakes by analyzing the error (Lack of knowledge about a certain grammatical point; A careless one or a mis-learned rule?) and plans strategies accordingly.

\section{References}

Burns, A (2009). The Cambridge guide to research in language teaching and learning (pp.289-297). Chapter: Action research in second language teacher education. Cambridge: Cambridge university press

Hopkins, D (2008). A teacher's guide to classroom action research 
( $3^{\text {rd }}$ ed.). Buckingham: Open University.

Huynh, Hai K.P (2013). Getting Students Actively Involved Using "the Mistake Buster "technique. English Teaching Forum, IX (11), 1-3.

Jaya, A. Habibi, A. 2016. Fishbowl Technique and Learning Interest Effects on Speaking Achievement of SMK Sembawa. Jambi-English Language Teaching. 1(1)

Jaya, A. Hermansyah, Mortini, A. 2018. The Effect of Crawford Series Teaching (CST) on the Students' Writing Achievement. ESTEEM: Journal of English Study Program. 1(1).

Nozadze, Alexandra (2012). Dealing with Fossilized Errors while Teaching Grammar. Journal of Education, 1(1):41-46. 